\title{
Effect of soybean hulls on lactation curves and the composition of goat milk
}

\author{
Maximiliane Alavarse Zambom ${ }^{1}$, Claudete Regina Alcalde ${ }^{2}$, Ludmila Couto Gomes ${ }^{3^{*}}$, Carlos \\ Eduardo Crispim de Oliveira Ramos ${ }^{4}$, Robson Marcelo Rossi ${ }^{5}$, Daniele Cristina da Silva \\ Kazama $^{6}$
}

\footnotetext{
${ }^{1}$ Universidade Estadual do Oeste do Paraná, Centro de Ciências Agrárias, Marechal Cândido Rondon, PR, Brazil.

2 Universidade Estadual de Maringá, Departamento de Zootecnia, Maringá, PR, Brazil.

${ }^{3}$ Universidade Federal do Sergipe, Departamento de Zootecnia, São Cristóvão, SE, Brazil.

${ }^{4}$ Universidade Federal do Recôncavo da Bahia, Centro de Ciências Agrárias, Ambientais e Biológicas, Cruz das Almas, BA, Brazil.

${ }^{5}$ Universidade Estadual de Maringá, Departamento de Estatística, Maringá, PR, Brazil.

${ }^{6}$ Universidade Federal de Santa Catarina, Departamento de Zootecnia e Desenvolvimento Rural, Florianópolis, SC, Brazil.
}

ABSTRACT - This study aimed to evaluate the effects of soybean hulls (SBH) as a ground corn replacement $(0,50$, and $100 \% \mathrm{SBH}$ ) on the parameters of the lactation curve and on lactation curves and milk composition. Fourteen multiparous Saanen goats were used during their lactation period, from kidding until the drying of their milk on the 228th day of lactation, and were distributed in a completely randomised design. The data was analysed using Bayesian methodology to minimise the effect of the low number of animals and to allow for comparison of the curve parameters estimated by Wood's nonlinear model. The SBH had no effect on the initial milk yield; nevertheless, the SBH reduced the rate of yield until lactation peak and accelerated the declining rate of yield after lactation. The treatments did not affect dry matter intake. The inclusion of SBH increased the fat content in the milk, which was also influenced by the lactation stage of the goats. Effects were observed on polyunsaturated fatty acids (PUFA), PUFA/total AG ratio, and the n-6:n-3 ratio of goat milk fat. The lactation stage changed the content of saturated fatty acid, monounsaturated fatty acid, and C18:2 (conjugated linoleic acid). The SBH can therefore be used as a ground corn replacement in the diets of lactating goats, as changes in the lactation curve parameters did not result in changes in total yields. Nevertheless, if the milk fat increases, then as quality rises, so could payment by quality, and thus an increase in profit margins per liter of milk sold.

Key Words: Bayesian methodology, dairy goat, peak production, persistence of lactation, Wood's nonlinear model

\section{Introduction}

Goat farming is of great social importance in the world and is bound inextricably to family-based farming. To provide an income to farmers, new food management alternatives are necessary to remunerate farmers and make the goat milk and its derivatives available in the market. NRC (2007) describes many kinds of alternative feeds and coproducts that are used to feed small ruminants. There is still a need for further research into new feeds to enlarge the set of potential food.

Received: May 2, 2016

Accepted: October 19, 2016

*Corresponding author: ludmilagomes@zootecnista.com.br http://dx.doi.org/10.1590/S1806-92902017000200012

How to cite: Zambom, M. A.; Alcalde, C. R.; Gomes, L. C.; Ramos, C. E. C. O.; Rossi, R. M. and Kazama, D. C. S. 2017. Effect of soybean hulls on lactation curves and the composition of goat milk. Revista Brasileira de Zootecnia 46(2):167-173.

Copyright ( 2017 Sociedade Brasileira de Zootecnia. This is an Open Access article distributed under the terms of the Creative Commons Attribution License (http://creativecommons.org/licenses/by/4.0/), which permits unrestricted use, distribution, and reproduction in any medium, provided the original work is properly cited.
The soybean hull ( $\mathrm{SBH})$ is a thin skin surrounding soybean grains. For soybean oil extraction, the hull is separated from the grain. The soybean hull is a coproduct that, normally, is ground and added to soybean meal in different proportions according to the protein level required for the soybean meal. Due to market demand for the nutritional requirements of poultry and pork, for soybean meal with a higher protein concentration $(48 \%)$, minor proportions of hull are added to the soybean meal. The soybean hull is thus a coproduct that may be used to feed ruminants in place of corn grain.

Goat milk yield and quality are associated with diet (Queiroga and Costa, 2004), breed, lactation stage, and climate, in addition to the combined action of these factors in the environmental conditions of each country or region. Ribeiro et al. (1997) and Queiroga and Costa (2004), studying dairy goats, showed that the contents of protein, fat, and lactose change during lactation. The study of lactation curves combined with the study of the effect of alternative feeds on dairy animals can help to plan nutritional management to optimise yield and quality and to provide an estimate of lactation persistence, time of peak 
yield, and the milk yield in the peak, which are criteria used for animal selection.

There are different models for the study of goat lactation curves: Wood (1967), Cobby and Le Du (1978), Dhanoa (1981), and Cappio-Borlino et al. (1995). Wood's model has been adopted in the majority of lactation curve studies because it allows for the estimation of basic curve features, such as the highest milk yield, the time to reach this level of production, and its persistency, using only three parameters (Wood, 1967).

Macedo et al. (2001), studying crossbred Saanen goats, concluded that Wood's nonlinear model was the best to describe the lactation curve because it showed less variance than the other models tested. Takma et al. (2009) concluded that Wood's nonlinear model can be used to describe the goat yields.

To obtain more accurate estimates of frequentist analysis, without making changes into the data, Bayesian analysis has been increasingly used. Bayesian methodology has been successfully used in studies about lactation curves (Chang et al., 2001; Silva et al., 2005; Gomes et al., 2014), since it considers all parameters as random variables, which substantially reduces the number of atypical curves.

Studies evaluating the impact of alternative feeds, as of soybeans hulls, on lactation curves and milk quality are important for providing animal nutritional management strategies. This study evaluates the parameters from the lactation curve and lactation curves and milk composition of Saanen goats receiving diets with soybean hulls as a corn ground replacement.

\section{Material and Methods}

The experiment was conducted in Maringá, Paraná State, southern Brazil. Fourteen multiparous Saanen goats $(75.17 \pm 9.96 \mathrm{~kg})$, between four and five years of age, and in the third or fourth lactation were used, from parturition of goats until natural drying on the 228th day of lactation. Goats were distributed in a completely randomised design as follows: $\mathrm{n}=3$ for $0 \% \mathrm{SBH}, \mathrm{n}=5$ for $50 \% \mathrm{SBH}$, and $\mathrm{n}=6$ for $100 \% \mathrm{SBH}$. The different replicates of animals are due to the death of some animals soon after kidding. The criteria used to put the animals in the treatments were milk yield, body weight, age, and parity orders.

Animals were housed in individual stalls with ad libitum water and access to a solarium in the mornings for $2 \mathrm{~h}$. Milking was done twice daily, at 07.30 and $15.00 \mathrm{~h}$, followed by milk weighing, and goats were fed at 10:00 and 16:00 $\mathrm{h}$.
Treatments were diets with SBH (with $926 \mathrm{~g} / \mathrm{kg}$ of dry matter (DM); $154 \mathrm{~g} / \mathrm{kg}$ of crude protein (CP); $36 \mathrm{~g} / \mathrm{kg}$ of ether extract (EE); $607 \mathrm{~g} / \mathrm{kg}$ of neutral detergent fibre (NDF); and $1.4 \mathrm{~g} / \mathrm{kg}$ of starch) as a corn ground replacement $(0$, 50 , and $100 \% \mathrm{SBH}$ ) (Table 1). Diets were calculated to attend the nutritional requirements of Saanen goats with body weights of $60 \mathrm{~kg}$ and a milk yield of $3.0 \mathrm{~kg}$ per day according to AFRC (1993) for energy and metabolizable protein and according to NRC (1981) for mineral requirements.

Feed intake and orts were measured daily and feed intake was adjusted weekly to provide approximately $10 \%$ orts. After parturition, goats and their kids were weighed and then were weighed biweekly.

Diets were collected and ground through a 1-mm sieve screen to evaluate: DM, ash, CP, and EE, as described by Silva and Queiroz (2002). The neutral detergent fibre and acid detergent fibre were evaluated as described by Van Soest et al. (1991); analyses of NDF were done without the use of sodium sulfite and with the inclusion of heat-stable $\alpha$-amylase (alpha-amylase Termamyl 2x, Tecnoglobo ${ }^{\circledR}$, Curitiba, PR, Brazil). Organic matter was estimated according to equations described by Sniffen et al. (1992). For starch, the enzyme method of Poore et al. (1989) was used, adapted by Pereira and Rossi (1995).

Table 1 - Ingredients and chemical composition of diets (g/kg DM)

\begin{tabular}{lccc}
\hline & \multicolumn{3}{c}{ Level of soybean hulls $(\mathrm{SBH})^{1}$} \\
\cline { 2 - 4 } Ingredient $(\mathrm{g} / \mathrm{kg})$ & $0 \% \mathrm{SBH}$ & $50 \% \mathrm{SBH}$ & $100 \% \mathrm{SBH}$ \\
\hline Corn silage & 400 & 400 & 400 \\
Soybean meal & 173 & 183 & 168 \\
Ground corn & 402 & 202 & 0 \\
Soybean hulls & 0 & 195 & 413 \\
Salt & 12.1 & 12.1 & 12.2 \\
Limestone & 6.30 & 2.50 & 0 \\
Dicalcium phosphate & 1.90 & 1.40 & 1.60 \\
Mineral-vitamin supplement ${ }^{2}$ & 5.00 & 5.00 & 5.00 \\
& & & \\
Chemical composition $(\mathrm{g} / \mathrm{kg} \mathrm{DM})$ & & & \\
Dry matter (g/kg) & 650 & 655 & 661 \\
Organic matter & 943 & 938 & 931 \\
Crude protein & 134 & 148 & 153 \\
Neutral detergent fibre & 313 & 396 & 489 \\
Acid detergent fibre & 161 & 238 & 322 \\
Calcium & 4.10 & 3.60 & 3.80 \\
Phosphorus & 2.60 & 2.40 & 2.30 \\
Total digestible nutrients & \\
Metabolizable energy $^{4}(\mathrm{Mcal} / \mathrm{kg}$ of DM) & 28.8 & 27.2 & 25.4 \\
\hline
\end{tabular}

DM - dry matter.

${ }^{1}$ Level of soybean hulls as a corn ground replacement.

${ }^{2}$ Chemical composition (per kg of commercial product): $80.00 \mathrm{~g} \mathrm{Ca} ; 65.00 \mathrm{~g} \mathrm{P}$ $126.00 \mathrm{mg} \mathrm{Co} ; 21.00 \mathrm{mg} \mathrm{Mg} ; 4400.00 \mathrm{mg} \mathrm{Mn} ; 185.00 \mathrm{mg} \mathrm{Na} ; 4680.00 \mathrm{mg} \mathrm{Zn}$; $45.00 \mathrm{mg} \mathrm{Se} ; 60.00 \mathrm{mg} \mathrm{I} ; 23.00 \mathrm{~g} \mathrm{~S} ; 615.79 \mathrm{mg} \mathrm{F}$ (max.); $7000.00 \mathrm{mg}$ niacin.

${ }^{3}$ Estimated according to the equation described by Sniffen (1992): TDN $=$ CPd + $(2.25 \times \mathrm{EEd})+\mathrm{TCd}$, in which $\mathrm{CPd}=$ digestible crude protein, $\mathrm{EEd}=$ digestible ether extract, and TCd $=$ digestible total carbohydrates.

${ }^{4}$ Estimated according to the equations described by NRC (2007). 
Milk samples were collected monthly from each goat by two consecutive milking acts and pooled on a yield basis. Thus, eight milk samples per goat were carried out. To determine chemical composition, milk samples were stored at $4{ }^{\circ} \mathrm{C}$ with a preservative (2-bromo-2-nitropropane-1,3diol) until analysed for fat, protein, lactose, and total solids by infrared spectroscopy (Bentley model 2000; Bentley Instrument Inc., Chaska, MN). Milk somatic cell count were obtained using an electronic counter (Somacount 500, Chaska, MN), which was calibrated for cow milk analysis.

Another milk sample was collected and frozen at $-20^{\circ} \mathrm{C}$ without the addition of preservatives to determine the milk fat composition and milk urea nitrogen.

Milk samples were centrifuged for $30 \mathrm{~min}$ at 3,000 $\times \mathrm{g}$ at $4{ }^{\circ} \mathrm{C}$ and the serum was separated and frozen at $-20{ }^{\circ} \mathrm{C}$ for subsequent analyses. The concentration of milk urea nitrogen was analysed using a commercial kit (urea-PP kit category 427; Gold AnalisaDiagnostica ${ }^{\circledR}$ ) on a spectrophotometer (Shimadzu UV-1601 UV-Visible Spectrophotometer ${ }^{\circledR}$ ) at wavelength of $600 \mathrm{~nm}$.

Milk fat was extracted by centrifugation for $30 \mathrm{~min}$ at $3000 \times g$ at $4{ }^{\circ} \mathrm{C}$ and transesterified according to method no. 5509 (ISO, 2000) with $\mathrm{KOH} /$ methanol and n-heptane. Thereafter, the methyl ester composition of fatty acids (FA) was measured by gas chromatography (14-A (Shimadzu ${ }^{\circledR}$ ) equipped with an auto sampler, a flame ionization detector at $240{ }^{\circ} \mathrm{C}$, and a cyanoalkyl polisiloquixano capillary column (100 m long, $0.25 \mathrm{~mm}$ internal diameter, and $0.20 \mathrm{~m}$ film thickness, CP-Sil 88 Chrompack $\left.^{\circledR}\right)$.

Fatty acids were quantified as $\mathrm{g} / 100 \mathrm{~g}$ lipids, compared to the retention time of methyl ester fatty acids from the sample standard tricosanoic acid methyl ester (23:0) (Sigma-Aldrich $^{\circledR}$, Brazil). The column parameters were as follows: the initial column temperature of $60{ }^{\circ} \mathrm{C}$ was maintained for $4 \mathrm{~min}$; the temperature was then increased at a rate of $40{ }^{\circ} \mathrm{C} / \mathrm{min}$ to $140{ }^{\circ} \mathrm{C}$; this temperature was maintained for $10 \mathrm{~min}$ and then increased at a rate of $5{ }^{\circ} \mathrm{C} /$ min to $225^{\circ} \mathrm{C}$ and maintained for $12 \mathrm{~min}$. The injector and detector temperatures were 220 and $240{ }^{\circ} \mathrm{C}$, respectively. The gas flow was $1.2 \mathrm{~mL} / \mathrm{min}$ for hydrogen (carrier gas), $30 \mathrm{~mL} / \mathrm{min}$ for $\mathrm{N}_{2}$ (auxiliary gas), $30 \mathrm{~mL} / \mathrm{min}$ for $\mathrm{H}_{2}$, and $300 \mathrm{~mL} / \mathrm{min}$ for compressed air. With a microliter syringe, $1.0 \mu \mathrm{L}$ of the samples were injected with a split ratio of 1:100. Fatty acid peaks were identified by comparison with the retention times of pure methyl ester standards (SigmaAldrich $^{\circledR}$, Brazil).

To obtain the tendency of milk yield data, the daily yield was adjusted by non-linear regression to predict the lactation curve parameters and the peak yield, time of peak yield, and lactation persistence according to Wood's nonlinear model was assumed, according to the equation described by Wood (1967):

$$
y_{i j k}=a_{k} t_{i j k}^{b_{k}} e^{-c_{k} t_{i j k}}
$$

in which $i$-animal $=1,2, \ldots \mathrm{N} ; j$-time $=1,2, \ldots \mathrm{J}$; $k$-treatment $=1,2, \ldots \mathrm{K} ; \mathrm{y}=$ milk yield $(\mathrm{kg} /$ day $) ; \mathrm{a}=$ the initial milk yield $(\mathrm{kg}) ; \mathrm{b}=$ increased rate of yield until lactation peak; $\mathrm{c}=$ the declined rate of yield after lactation peak (persistency factor); $\mathrm{t}=$ days in lactation; $\mathrm{e}=$ exponential.

Using Wood's model, the following parameters were determined: peak yield (pp), time of peak yield (dpp), and lactation persistence (s) by the equations:

$$
\begin{gathered}
p p=a\left(\frac{b}{c}\right)^{b} e^{-b} \\
d p p=\frac{b}{c} \\
s=-(b+1) \ln (c)
\end{gathered}
$$

To reduce experimental bias due to the low repetitions of animals and to compare the lactation curve parameters among treatments, Bayesian analysis was used for the lactation curves and milk yield.

Normal distribution data were considered to analyse the lactation curve parameters, i.e. $y_{i} \sim N\left(f\left(t_{i}\right) ; \sigma^{2}\right)$, in which $f\left(t_{i}\right)$ is the nonlinear Wood function (1967). Non-informative Priors were considered for the parameters of the model. A gamma distribution was assumed for parameter $a$ and a uniform distribution for parameters $b$ and $c: a \sim \operatorname{Gamm} a\left(10^{-3}, 10^{-3}\right)$; $b$ and $c \sim \operatorname{Uniform}(0,1) ; \sigma^{2} \sim \operatorname{Gamma}\left(10^{-3}, 10^{-3}\right)$ as Open BUGS parameterization.

To evaluate the total milk yield ( $\mathrm{kg})$, it was assumed that the response $\left(Y_{i j}\right)$ had a normal distribution, i.e. $Y_{i j} \sim \mathrm{N}\left(\mu_{j}, \sigma_{j}^{2}\right)$, $i=1,2, \ldots$ for the $j$-th levels of treatment. For each $\mu_{j}$ and $\sigma_{j}^{2}$ non-informative Priors were considered, respectively, $\mu_{j} \sim \mathrm{N}\left(0,10^{-6}\right)$ and $\sigma_{j}^{2} \sim \operatorname{Gamma}\left(10^{-3}, 10^{-3}\right)$ as Open BUGS parameterization.

The model used to evaluate the total milk yield was as follows:

$$
Y_{i j}=\mu+\alpha_{i}+e_{i j}
$$

in which $Y_{i j}=$ total milk yield of animal $i$ at treatment $j$; $\mu=$ constant inherent in every observation; $\alpha_{j}=$ treatment effect $j$; $j=1,2,3(0 \% \mathrm{SBH}, 50 \% \mathrm{SBH}$, and $100 \% \mathrm{SBH}) ; e_{i j}=$ random error associated with each observation.

The multiple comparison procedure was based on the a posteriori samples of the estimates of the parameters. Significant differences were considered at the level of 5\% among the treatments if the zero value was not contained in the credibility interval of the desired contrast. The marginal posterior distributions for all parameters were taken by R software (R Development Core Team, 2015) 
using the BRugs package. For each parameter, 1,100,000 values were generated in an MCMC (Monte Carlo Markov Chain) process, considering a sample discard period of 100,000 initial values. The final sample was taken with steps of 100 , which means that for every 100 values taken, one was included in the sample, with 10,000 values generated. The convergence of the final chains was checked using the test described by Heidelberger and Welch (1983) and the R software by CODA package.

Body weight, dry matter intake, and milk composition were assumed as a normal distribution and all frequentist premises were attended for MANOVA (Multivariate Analysis of Variance), depending on the level of SBH as a corn ground replacement $(0 \% \mathrm{SBH}, 50 \% \mathrm{SBH}$, and $100 \% \mathrm{SBH}$ ); lactation stages (beginning, middle, and end) were statistically analysed by MANOVA through a Pillai Trace test; and multiple comparisons were made using the Bonferroni test at the $5 \%$ level of significance according to the model:

$$
Y_{i j}=\mu+\alpha_{i}+\beta_{j}+\alpha_{i} \beta_{j}+e_{i j}
$$

in which $Y_{i j}=$ the vector of multivariate responses; $\mu=$ general constant; $\alpha_{i}=$ effect of diets $i ; \beta_{j}=$ effect of lactation stage $j$; and $e_{i j}=$ random error.

\section{Results}

The addition of SBH as a corn ground replacement to the diet of Saanen goats had no effect on initial milk yield (parameters $a$ ); however, the increased rate of yield until lactation peak (parameters $b$ ) and the declined rate of yield after lactation peak (parameters $c$ ) decreased due to the increased inclusion of SBH (Figure 1 and Table 2).

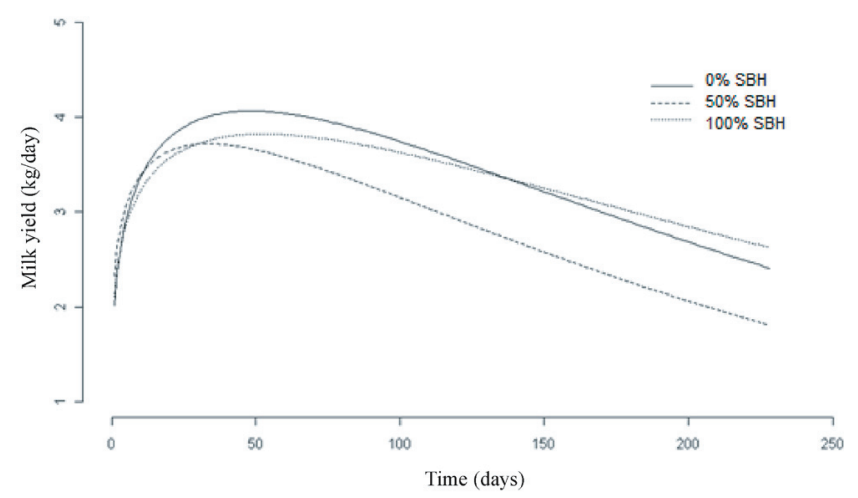

Level of soybean hulls $(\mathrm{SBH})$ as a corn ground replacement $(0,50$, and $100 \% \mathrm{SBH})$.

Figure 1 - Lactation curves adjusted for Saanen goats receiving diets with soybean hulls.
The goats that received diets with $\mathrm{SBH}$ as a corn ground replacement had changes in the increase and decline rates of milk yield; however, no effect on total milk yield was observed (Table 3).

Body weight was affected by treatments. Goats fed $50 \%$ SBH showed higher body weight $(\mathrm{P}<0.05)$ due to the higher milk yield from other treatments. Body weight was not affected by the lactation stage. The addition of SBH as a corn ground replacement for Saanen goats had no effect on dry matter intake $(\mathrm{P}<0.05)$.

When observing the major classes of fatty acids in milk, there was an effect on polyunsaturated fatty acids (PUFA), on PUFA:total FA, and n-6:n-3, while the lactation stage affected the content of saturated FA, monounsaturated, and conjugated linoleic acid (18: 2) (Table 5).

Table 2 - Values of Wood's nonlinear model parameters with their credibility intervals $\left(\mathrm{p}_{2.5 \%}-\mathrm{p}_{97.5 \%}\right)$, in level of $95 \%$, for Saanen goats receiving diets with soybean hulls

\begin{tabular}{|c|c|c|c|c|c|c|}
\hline Treatment $^{1}$ & Parameter $^{2}$ & Mean & SE & Median & $\mathrm{P}_{2.5 \%}$ & $P_{97.5 \%}$ \\
\hline $0 \% \mathrm{SBH}$ & \multirow{3}{*}{$a$} & 2.0270 & 0.1400 & 2.0250 & 1.7610 & 2.3080 \\
\hline $50 \% \mathrm{SBH}$ & & 2.3370 & 0.1335 & 2.3370 & 2.0840 & 2.6000 \\
\hline $100 \% \mathrm{SBH}$ & & 2.1130 & 0.2423 & 2.1020 & 1.6650 & 2.6160 \\
\hline $0 \% \mathrm{SBH}$ & \multirow{3}{*}{$b$} & $0.2417 \mathrm{a}$ & 0.0222 & 0.2412 & 0.1996 & 0.2860 \\
\hline $50 \% \mathrm{SBH}$ & & $0.1851 b$ & 0.0190 & 0.1847 & 0.1493 & 0.2222 \\
\hline $100 \% \mathrm{SBH}$ & & $0.2002 \mathrm{ab}$ & 0.0365 & 0.2004 & 0.1297 & 0.2733 \\
\hline $0 \% \mathrm{SBH}$ & \multirow{3}{*}{$c$} & $0.0050 \mathrm{ab}$ & 0.0003 & 0.0050 & 0.0044 & 0.0056 \\
\hline $50 \% \mathrm{SBH}$ & & $0.0055 \mathrm{a}$ & 0.0003 & 0.0055 & 0.0049 & 0.0061 \\
\hline $100 \% \mathrm{SBH}$ & & $0.0038 b$ & 0.0005 & 0.0038 & 0.0028 & 0.0048 \\
\hline $0 \% \mathrm{SBH}$ & \multirow{3}{*}{$d p p$} & $48.2900 \mathrm{~b}$ & 2.1260 & 48.3200 & 44.0100 & 52.3500 \\
\hline $50 \% \mathrm{SBH}$ & & $33.4100 \mathrm{~b}$ & 2.0090 & 33.4300 & 29.3600 & 37.1800 \\
\hline $100 \% \mathrm{SBH}$ & & $52.2400 \mathrm{a}$ & 4.6350 & 52.3500 & 42.7200 & 61.1000 \\
\hline $0 \% \mathrm{SBH}$ & \multirow{3}{*}{$p p$} & $4.0560 \mathrm{a}$ & 0.0478 & 4.0560 & 3.9620 & 4.1490 \\
\hline $50 \% \mathrm{SBH}$ & & $3.7150 \mathrm{~b}$ & 0.0437 & 3.7150 & 3.6290 & 3.8010 \\
\hline $100 \% \mathrm{SBH}$ & & $3.8000 \mathrm{~b}$ & 0.0782 & 3.7990 & 3.6470 & 3.9540 \\
\hline $0 \% \mathrm{SBH}$ & \multirow{3}{*}{$s$} & $6.5800 \mathrm{a}$ & 0.0571 & 6.5790 & 6.4720 & 6.6930 \\
\hline $50 \% \mathrm{SBH}$ & & $6.1610 \mathrm{~b}$ & 0.0511 & 6.1600 & 6.0610 & 6.2620 \\
\hline $100 \% \mathrm{SBH}$ & & $6.6900 \mathrm{a}$ & 0.0938 & 6.6880 & 6.5080 & 6.8800 \\
\hline
\end{tabular}

${ }^{1}$ Level of soybean hulls (SBH) as a corn ground replacement.

${ }^{2}$ Wood's model parameters: $a$ - initial milk yield; $b$ - increase rate of yield until lactation peak; $c$ - decline rate of yield in the after lactation peak; $d p p$ - time of peak yield; $p p$ - peak yield; and $s$ - lactation persistence.

$\mathrm{SE}$ - standard error of the mean.

Different letters among diets indicate differences for means.

Table 3 - Total milk yield $(\mathrm{kg})$ calculated from the Wood's nonlinear model parameters with their credibility intervals $\left(\mathrm{p}_{2.5 \%}-\mathrm{p}_{97.5 \%}\right)$, in level of $95 \%$, for Saanen goats receiving diets with soybean hulls

\begin{tabular}{lccccc}
\hline Treatments $^{1}$ & Mean & SE & Median & $\mathrm{P}_{2.5 \%}$ & $\mathrm{P}_{97.5 \%}$ \\
\hline $0 \% \mathrm{SBH}$ & 751.70 & 170.50 & 763.30 & 383.50 & 1040.00 \\
$50 \% \mathrm{SBH}$ & 651.50 & 106.20 & 654.20 & 431.50 & 855.20 \\
$100 \% \mathrm{SBH}$ & 720.50 & 210.90 & 727.60 & 272.10 & 1122.00 \\
\hline
\end{tabular}

${ }^{1}$ Level of soybean hulls (SBH) as a corn ground replacement.

$\mathrm{SE}$ - standard error of the mean. 


\section{Discussion}

By evaluating the lactation curves of Saanen goats through Wood's nonlinear model, Takma et al. (2009) showed that the increased rate of yield until lactation peak was 0.13 and Gomes et al. (2014) showed a range from 0.03 to 0.13 . Nevertheless, in this research, the rate of yield increased from 0.18 to 0.24 , which agrees with Zambom et al. (2005), who found values ranging from 0.10 to 0.27 , and Tufarelli et al. (2009), whose values ranged from 0.21 to 0.29 for the increased rate of yield until lactation peak. The largest values in this research may be related to animal genetics, intake of dry matter, or diet compositions.

The lactation peak has a negative correlation with lactation persistency and, therefore, animals with greater persistency tend to have a less pronounced lactation peak (Guimarães et al., 2006). Goats receiving diets with 50\% $\mathrm{SBH}$ as a corn ground replacement showed an increased effect on the declined rate of yield after the lactation peak and a decrease in peak yield, which resulted in lower lactation persistency.

The higher increased rate of yield until lactation peak resulted in higher yield at peak for goats receiving diets without SBH $(0 \% \mathrm{SBH})$, which may be explained by the energy level of diets. However, this effect did not influence the total milk yield (Table 3).

The addition of SBH in the diet of goats decreased diet energy, but did not influence total milk yield. This shows the potential of using SBH to replace ground corn in goat diets. Goats fed a diet with low energy level maintained the same milk yield that goats fed a diet with high energy level. Probably, the mobilization of body fat was greater for goats fed low energy diets to maintain the same production level of other goats.

The goat lactation peak occurred at 48 days with a milk yield of $2.65 \mathrm{~kg} /$ day. Zambom et al. (2005) fed goats diets containing $419 \mathrm{~g} / \mathrm{kg} \mathrm{NDF}, 153 \mathrm{~g} / \mathrm{kg} \mathrm{CP}$, and $817 \mathrm{~g} / \mathrm{kg}$ total digestible nutrients, and showed the lactation peak (calculated by nonlinear Wood's model) at 47 days close to the values found in the present study, however with a greater milk yield $(3.35 \mathrm{~kg} /$ day $)$ than the one found in the present research. According to AFRC (1993), the lactation peak of Saanen goats is approximately 45 days. It is noteworthy that the nutritional requirements in this study were according to AFRC (1993) for Saanen goats with body weights of $60 \mathrm{~kg}$ and a milk yield of $3.0 \mathrm{~kg}$ per day, and that the data obtained in this study was thus similar to that predicted by this nutrition council.

Table 4 - Body weight, dry matter intake, and milk composition for Saanen goats receiving diets with soybean hulls

\begin{tabular}{|c|c|c|c|c|c|c|}
\hline & \multicolumn{3}{|c|}{ Treatment $^{1}$} & \multicolumn{3}{|c|}{ Lactation stage } \\
\hline & $0 \% \mathrm{SBH}$ & $50 \% \mathrm{SBH}$ & $100 \% \mathrm{SBH}$ & Beginning & Middle & End \\
\hline Body weight (kg) & $74.13 \mathrm{ab}$ & $81.87 \mathrm{a}$ & $72.47 b$ & 72.28 & 76.99 & 79.20 \\
\hline Dry matter intake (kg/day) & 2.43 & 2.19 & 2.49 & 2.36 & 2.55 & 2.21 \\
\hline \multicolumn{7}{|l|}{ Milk composition $(\%)$} \\
\hline Fat & $3.11 \mathrm{~b}$ & $3.26 \mathrm{a}$ & $3.62 \mathrm{a}$ & $3.24 b$ & $3.11 \mathrm{~b}$ & $3.64 \mathrm{a}$ \\
\hline Protein & 2.87 & 2.93 & 2.83 & 2.88 & 2.83 & 2.91 \\
\hline Lactose & 4.35 & 4.16 & 4.17 & 4.35 & 4.21 & 4.12 \\
\hline Total solids & 11.20 & 11.20 & 11.48 & 11.37 & 11.05 & 11.45 \\
\hline Somatic cell count $(\log 10)$ & 2.90 & 3.17 & 2.94 & 2.85 & 3.05 & 3.11 \\
\hline Urea nitrogen (mg/dL) & $19.00 \mathrm{~b}$ & $17.69 b$ & $23.29 \mathrm{a}$ & $15.46 b$ & $23.27 \mathrm{a}$ & $21.24 \mathrm{a}$ \\
\hline
\end{tabular}

${ }^{1}$ Level of soybean hulls (SBH) as a corn ground replacement.

a,b,c - Different letters indicate differences in the $5 \%$ level of significance after Pillai trace by Bonferroni test.

Note: There was no interaction effect; it was therefore removed from the model.

Table 5 - Fatty acids (FA) in milk for Saanen goats receiving diets with soybean hulls

\begin{tabular}{|c|c|c|c|c|c|c|}
\hline \multirow{2}{*}{$\mathrm{g} / 100 \mathrm{~g}$ of fatty acids } & \multicolumn{3}{|c|}{ Treatment $^{1}$} & \multicolumn{3}{|c|}{ Lactation stage } \\
\hline & $0 \% \mathrm{SBH}$ & $50 \% \mathrm{SBH}$ & $100 \% \mathrm{SBH}$ & Beginning & Middle & End \\
\hline Short and medium-chain & 20.49 & 20.97 & 20.95 & 19.99 & 20.91 & 21.51 \\
\hline Long-chain & 77.17 & 77.25 & 77.41 & 78.05 & 77.31 & 76.47 \\
\hline Saturated FA & 66.04 & 67.83 & 68.98 & $65.30 \mathrm{~b}$ & $70.60 \mathrm{a}$ & $66.95 \mathrm{ab}$ \\
\hline Monounsaturated FA & 39.50 & 38.77 & 37.45 & $39.88 \mathrm{a}$ & $36.62 b$ & $39.23 \mathrm{ab}$ \\
\hline Polyunsaturated FA (PUFA) & $3.71 \mathrm{a}$ & $3.21 \mathrm{~b}$ & $3.56 \mathrm{a}$ & 3.57 & 3.36 & 3.55 \\
\hline PUFA/total FA & $0.056 \mathrm{a}$ & $0.048 b$ & $0.052 \mathrm{ab}$ & 0.055 & 0.048 & 0.053 \\
\hline Conjugated linoleic acid & 0.50 & 0.47 & 0.54 & $0.42 b$ & $0.50 \mathrm{ab}$ & $0.59 \mathrm{a}$ \\
\hline$n-6: n-3$ & $12.82 \mathrm{a}$ & $12.23 \mathrm{a}$ & $6.60 \mathrm{~b}$ & 12.52 & 11.23 & 7.88 \\
\hline
\end{tabular}

${ }^{1}$ Level of soybean hulls (SBH) as a corn ground replacement.

a,b,c - Different letters indicate differences in the 5\% level of significance after Pillai trace by Bonferroni test.

Note: There was no interaction effect; it was therefore removed from the model. 
The milk yield at the beginning of lactation $(2.16 \mathrm{~kg} /$ day $)$ and at the peak ( $3.86 \mathrm{~kg} /$ day) was lower than reports of other studies for Saanen goats under tropical climate conditions, as mentioned by Gomes et al. (2014) and Souza et al. (2014), and close to that reported by Macedo et al. (2001) and Zambom et al. (2005). These differences must be due to the variations in the ingredients and compositions of diets.

The addition of SBH to the diet increased the milk fat content, which is probably a result of the higher NDF in the feed (SBH $607 \mathrm{~g} / \mathrm{kg}$ of NDF), which in turn promotes an increase in ruminal acetate (Zambom et al., 2007). Zervas et al. (1998), studying lactating sheep, and Ipharraguerre et al. (2002) and Hindrichsen et al. (2006), studying dairy cows, found no differences in dry matter intake and milk yield for animals receiving SBH. However, these authors identified a quadratic effect on the milk fat content when SBH was added to the diet.

Evaluation of the influence of lactation stage on milk quality demonstrated that there was difference across the months in milk fat content. This is explained by the dilution effect: the lower milk yield results in a higher concentration of fat content. However, that increase in milk fat content may result in an increase in profit margins for each litre of milk marketed when payment is made by quality.

Milk urea or milk urea nitrogen (urea $\times 0.466$ ) is an indicator of an adequate protein diet and, thus, is directly related to dietary protein content and energy intake and the interaction between these factors. The recommended milk urea nitrogen ranges from 8 to $14 \mathrm{mg} / \mathrm{dL}$ ( 17 to $30 \mathrm{mg} / \mathrm{dL}$ of urea); lower values of milk urea nitrogen indicate a deficiency of protein in the diet and higher values indicate excessive protein in the diet. As soybean hulls increased in the diet, the milk urea content also increased due to the SBH inclusion, which increased the protein content of the diet (Table 1), or the rumen synchronization between protein and carbohydrates, since the SBH have a lower amount of soluble carbohydrates than the ground corn (Goes et al., 2008). Goats at the beginning of lactation showed $15.46 \mathrm{mg} / \mathrm{dL}$ milk urea, which indicates protein use efficiency during the beginning of lactation, highlighting the importance of adjusting dietary protein content throughout each lactation stage.

The differences in concentrations of FA in milk may be associated with several factors, such as food processing, physiological stage, breed, and interaction among factors. Changes in the FA in milk are therefore commonly reported in the literature. When observing the major classes of FA in milk, there was an effect on PUFA, PUFA:total FA, and n-6:n-3, while the lactation stage affected the content of saturated FA, monounsaturated, and conjugated linoleic acid, (18: 2) (Table 5).

The changes observed in FA in the milk shows that the inclusion of SBH affects the de novo synthesis of some FA. The SBH may have influenced the production of acetate and beta-hydroxybutyrate, both precursors of FA via the de novo synthesis by the epithelial cells of the mammary gland (Palmquist et al., 1993). The value of 18:2 (conjugated linoleic acid) was close to that achieved by Lock and Garnsworthy (2003), which was $0.55 \mathrm{~g} / 100 \mathrm{~g}$ total lipid in cow milk.

Nowadays, in studies evaluating the influence of FA intake with human health, suitable intake levels of FA n-6, n-3, and n-6:n-3 are noted. According to Holman (1998) and Simopoulos et al. (1999), diets must provide a n-6:n-3 ratio of $4: 1$ or $5: 1$. Goats receiving the $100 \% \mathrm{SBH}$ diet showed an n-6:n-3 ratio close to that recommended in the literature. Ground corn replacement by SBH can thus be one strategy to improve milk quality.

\section{Conclusions}

This experiment demonstrates that soybean hulls can be used in diets as a ground corn replacement for lactating goats. Although there are changes in curve parameters, they do not result in changes in total milk yield.

\section{References}

AFRC - Agricultural and Food Research Council. 1993. Energy and protein requirements of ruminant. $\mathrm{CAB}$ International, Wallingford, UK.

Cappio-Borlino, A.; Pulina, G. and Rossi, G. 1995. A non-linear modification of Wood's equation fitted to lactation curves of Sardinian dairy ewes. Small Ruminant Research 18:75-79.

Chang, Y. M.; Rekaya, R.; Gianola, D. and Thomas, D. L. 2001. Genetic variation of lactation curves in dairy sheep: A Bayesian analysis of Wood's function. Livestock Production Science 71:241-251.

Cobby, J. and Le Du, Y. 1978. On fitting curves to lactation data. Animal Production 26:127-133.

Dhanoa, M. 1981. A note on an alternative form of the lactation model of Wood. Animal Production 32:349-351.

Goes, R. H. T. B.; Tramontini, R. C. M.; Almeida, G. D.; Cardim, S. T.; Ribeiro, J.; Oliveira, L. A.; Morotti, F.; Brabes, K. C. S. and Oliveira, E. R. 2008. Ruminal degradability of dry matter and crude protein of different by-products fed to steers. Revista Brasileira de Saúde e Produção Animal 9:715-725.

Gomes, L. C.; Alcalde, C. R.; Souza, R.; Molina, B. S. L.; Lourenço, D. A. L. and Martins, E. N. 2014. The impact of dietary dry yeast on lactation curves of primiparous and multiparous Saanen goats. Acta Scientiarum. Animal Sciences 36:405-411.

Guimarães, V. P.; Rodrigues, M. T.; Sarmento, J. L. R. and Rocha, D. T. 2006. Utilização de funções matemáticas no estudo da curva de lactação em caprinos. Revista Brasileira de Zootecnia $35: 535-543$ 
Heidelberger, P. and Welch, P. D. 1983. Simulation run length control in the presence of animal transient. Operations Research 31:1109-1144.

Hindrichsen, I. K.; Wettstein, H.-R.; Machmüller, A.; Knudsen, K. B.; Madsen, J. and Kreuzer, M. 2006. Digestive and metabolic utilisation of dairy cows supplemented with concentrates characterised by different carbohydrates. Animal Feed Science and Technology 126:43-61.

Holman, R. T. 1998. The slow discovery of the importance of $\omega 3$ essential fatty acids in human health. The Journal of Nutrition 128:427S-433S.

Ipharraguerre, I. R.; Ipharraguerre, R. R. and Clark, J. H. 2002. Performance of lactating dairy cows fed varying amounts of soyhulls as a replacement for corn grain. Journal of Dairy Science 85:2905-2912.

ISO - International Organization for Stardardization. 2000. Animal and vegetable fats and oils - Preparation of methyl esters of fatty acids ISO 5509:2000. International Organization for Stardardization, Geneva, Switzerland.

Lock, A. and Garnsworthy, P. 2003. Seasonal variation in milk conjugated linoleic acid and $\Delta 9$-desaturase activity in dairy cows. Livestock Production Science 79:47-59.

Macedo, V. P.; Damasceno, J. C.; Santos, G. T.; Martins, E. N. and Macedo, F. A. F. 2001. Comportamento da curva de lactação de cabras mestiças Saanen em função da suplementação de concentrado e do sistema de produção. Revista Brasileira de Zootecnia 30:2093-2098.

NRC - National Research Council. 1981. Nutrient requirements of goats. 7th ed. National Academies Press, Washington, D.C.

NRC - National Research Council. 2007. Nutrient requirements of small ruminants. National Academies Press, Washington, D.C.

Palmquist, D. L.; Beaulieu, A. D. and Barbano, D. M. 1993. Feed and animal factors influencing milk fat composition. Journal of Dairy Science 76:1753-1771.

Pereira, J. R. A. and Rossi, P. 1995. Manual prático de avaliação nutricional de alimentos. 1.ed. Fundação de Estudos Agrários Luiz de Queiroz, Piracicaba.

Poore, M. H.; Eck, T. P.; Swingle, R. S. and Theurer, C. B. 1989. Total starch and relative starch availability of feed grains. p.35. In: Biennial Conference on Rumen Function, Chicago. Society for Rumen Function, Chicago.

Queiroga, R. C. R. E. and Costa, R. G. 2004. Qualidade do leite caprino. p.161-171. In: Simpósio Internacional de Conservação de Recursos Genéticos - Raças Nativas para o Semi-árido. Recife.

Ribeiro, M.; Albuquerque, L. and Pimenta Filho, E. 1997. Comparação de funções matemáticas no ajuste da curva de lactação de cabras mestiças no Cariri Paraibano. p.272-274. In: Anais da $34^{\mathrm{a}}$ Reunião Anual da Sociedade Brasileira de Zootecnia, Juiz de Fora.

Silva, D. J. and Queiroz, A. C. 2002. Análise de alimentos: métodos químicos e biológicos. 3.ed. Universidade Federal de Viçosa, Viçosa, MG.

Silva, F. F.; Muniz, J. A.; Aquino, L. H. and Sáfadi, T. 2005. Abordagem Bayesiana da curva de lactação de cabras Saanen de primeira e segunda ordem de parto. Pesquisa Agropeccuária Brasileira 40:27-33

Simopoulos, A. P.; Leaf, A. and Salem Jr., N. 1999. Workshop on the essentiality of and recommended dietary intakes for omega- 6 and omega-3 fatty acids. Journal of the American College of Nutrition $18: 487-489$.

Souza, R.; Alcalde, C. R.; Oliveira, C. A. L.; Molina, B. S. L.; Macedo, F. A. F.; Gomes, L. C.; Hygino, B. and Possamai, A. P. S. 2014. Lactation curves and economic results of Saanen goats fed increasing dietary energy levels obtained by the addition of calcium salts of fatty acids. Revista Brasileira de Zootecnia 43:73-79.

Sniffen, C. J.; O'Connor, J. D.; Van Soest, P. J.; Fox, D. G. and Russell, J. B. 1992. A net carbohydrate and protein system for evaluating cattle diets: II. Carbohydrate and protein availability. Journal of Animal Science 70:3562-3577.

Takma, C.; Akbaș, Y. and Taskin, T. 2009. Modeling lactation curves of Turkish Saanen and Bornova goats. Asian Journal of Animal and Veterinary Advances 4:122-129.

Tufarelli, V.; Dario, M. and Laudadio, V. 2009. Forage to concentrate ratio in Jonica breed goats: influence on lactation curve and milk composition. Journal of Dairy Research 76:124-128.

Van Soest, P. J.; Robertson, J. B. and Lewis, B. A. 1991. Symposium: carbohydrate methodology, metabolism, and nutritional implications in dairy cattle. Journal of Dairy Science 74:3583-3597.

Wood, P. D. P. 1967. Algebraic model of the lactation curve in cattle. Nature 206:164-165.

Zambom, M. A.; Alcalde, C. R.; Hashimoto, J. H.; Macedo, F. A. F.; Passianoto, G. O. and Lima, L. S. 2007. Parâmetros digestivos, produção e qualidade do leite de cabras Saanen recebendo rações com casca do grão de soja em substituição ao milho. Acta Scientiarum. Animal Sciences 29:309-316.

Zambom, M. A.; Alcalde, C. R.; Martins, E. N.; Santos, G. T.; Macedo, F. A. F.; Horst, J. A. and Veiga, D. R. 2005. Curva de lactação e qualidade do leite de cabras Saanen recebendo rações com diferentes relações volumoso:concentrado. Revista Brasileira de Zootecnia 34:2515-2521.

Zervas, G.; Fegeros, K.; Koytsotolis, K.; Goulas, C. and Mantzios, A. 1998. Soy hulls as a replacement for maize in lactating dairy ewe diets with or without dietary fat supplements. Animal Feed Science and Technology 76:65-75. 